\title{
Third trimester fetal growth and umbilical venous blood concentrations of IGF-1, IGFBP-1, and
} growth hormone at term

\author{
J A D Spencer, T C Chang, J Jones, S C Robson, M A Preece
}

\begin{abstract}
Insulin-like growth factor-1 (IGF-1), insulin-like growth factor binding protein-1 (IGFBP-1) and growth hormone (GH) concentrations were measured in umbilical venous blood after delivery of 78 term newborn infants. Three groups of pregnancies were prospectively identified during the third trimester, according to fetal size and subsequent fetal growth, assessed by repeated ultrasound scans. Fetal size was considered either appropriate for gestational age (AGA) or small for gestational age (SGA), according to whether the first ultrasound measurement of abdominal circumference was equal to or above, or below the tenth centile for gestational age, respectively. Subsequent fetal growth was quantified by the change in the standard deviation score of abdominal circumference measurements between the first and last scans before delivery. Fetal growth retardation (FGR) was defined as a (negative) change in SD score of greater than $-1 \cdot 5$. Eighteen SGA fetuses with evidence of FGR had significantly lower IGF-1 (median 0.05 (range $0 \cdot 0-0 \cdot 24) \mathrm{U} / \mathrm{ml}$ ) at delivery than 35 SGA fetuses with normal growth (median 0.13 (range $0.0-0.94$ ) $\mathrm{U} / \mathrm{ml} ; P<0.05$ ) and 25 AGA fetuses with normal growth (median 0.31 (range $0.0-0.84$ ) U/ml; $P<0.05$ ). The median concentration in the SGA group with normal growth was also significantly lower than that of the AGA group with normal growth. There were no significant differences in IGFBP-1 or GH concentrations between the three groups.

These observations indicate that umbilical blood concentrations at birth of IGF-1, but not IGFBP-1 or GH, relate to both fetal size and fetal growth during the third trimester of pregnancies reaching term. (Arch Dis Child 1995; 73: F87-F90)
\end{abstract}

Keywords: umbilical blood, insulin-like growth factor-1, insulin-like growth factor binding protein-1, growth hormone.

Department of and Development, Institute of Child

Health, University of

London

$\mathrm{J}$ Jones

M A Preece

Correspondence to: Mr John A D Spencer, Department of Obstetrics and Gynaecology, Northwick Park Hospital NHS Trust,

Watford Road, Harrow,

Middlesex HA1 3 UJ.

Accepted 12 June 1995 birthweight and IGF-1 concentrations in umbilical venous blood at delivery, ${ }^{3-8}$ although one found an inverse correlation. ${ }^{9}$ In the circulation IGF-1 is bound to specific proteins and six IGF binding proteins (IGFBPs) have been described. 1011 Fetal concentrations of IGF-1 are low but studies suggest its half-life may be prolonged by being bound to IGFBP- $1^{12}$ and/or IGFBP-3. ${ }^{11}$ Reports of the association between birthweight and IGFBP-1 concentrations have generally shown a negative correlation, 6912 although one study did not find any association. ${ }^{7}$ Growth hormone (GH) does not appear to be related to birthweight. ${ }^{13}$

Studies of circulating concentration of IGF-1 and IGFBP-1 in the fetus have all used birthweight as a measure of fetal growth. However, low birthweight is a poor measure of fetal growth retardation ${ }^{14}$ which is better defined as reduced change in fetal size over time. ${ }^{1516}$

We designed a prospective study to relate umbilical vein concentrations of IGF-1, IGFBP-1, and GH at birth to fetal size and growth, assessed using repeated ultrasound measures of abdominal circumference during the third trimester of pregnancy.

\section{Methods}

Seventy eight pregnancies, thought clinically to be small during the third trimester, were recruited into the study following referral to the radiology department. In 53 cases the fetus was found to be SGA with an abdominal circumference of $<10$ th centile. ${ }^{16}$ A further 25 cases were AGA with an abdominal circumference between the 10th and 90th centiles. All women had been scanned between 18 and 21 weeks' gestation at which time measurements of biparietal diameter and femur length were consistent with being within seven days of certain menstrual dates. All pregnancies continued until 37 weeks or more. The study was approved by the hospital ethics committee and all women gave informed consent.

Fetal abdominal circumference was measured by ultrasound scans at intervals of one or two weeks on at least three occasions before delivery. At each scan the abdominal circumference value was expressed as a standard deviation (SD) score using our own, published, reference standards. ${ }^{16}$ The SD score was calculated as the measured abdominal circumference value minus the mean value for the gestation, divided by the SD of the mean for that gestation. Fetal growth was quantified by determining the change in SD score between 
Table 1 Description of groups according to fetal size and growth

\begin{tabular}{|c|c|c|c|}
\hline & \multirow{2}{*}{$\frac{\text { Normal size }}{\text { Normal growth }}$} & \multicolumn{2}{|c|}{ Small size (abdominal circumference of $<10$ th centile) } \\
\hline & & $\begin{array}{l}\text { Normal growth } \\
(n=35)\end{array}$ & $\begin{array}{l}\text { Growth retardation } \\
(n=18)\end{array}$ \\
\hline $\begin{array}{l}\text { Gestation (days) } \\
\text { Birthweight (g) } \\
\text { Ponderal index } \\
\text { MAC:HC ratio }\end{array}$ & $\begin{array}{c}274(254-289) \\
3570(3200-4200) \\
2 \cdot 60(2 \cdot 38-2 \cdot 98) \\
0 \cdot 31(0 \cdot 28-0 \cdot 35)\end{array}$ & $\begin{array}{c}269(253-290) \\
2659(1701-3120)^{\star} \\
2 \cdot 45(2 \cdot 13-2 \cdot 42)^{\star} \\
0.28(0 \cdot 22-0 \cdot 33)^{\star}\end{array}$ & $\begin{array}{c}272(257-292) \\
2277(1360-2900)^{\star} \dagger \\
2 \cdot 28(1 \cdot 90-2 \cdot 93)^{\star} \dagger \\
0 \cdot 26(0 \cdot 23-0 \cdot 30)^{\star} \dagger\end{array}$ \\
\hline $\begin{array}{l}\text { Skinfold thicknes } \\
\text { Subscapular } \\
\text { Triceps }\end{array}$ & nm) $\begin{array}{l}4 \cdot 6(2 \cdot 9-6 \cdot 1) \\
4 \cdot 7(3 \cdot 1-6 \cdot 2)\end{array}$ & $\begin{array}{l}3 \cdot 1(2 \cdot 2-4 \cdot 4)^{\star} \\
3 \cdot 1(2 \cdot 2-4 \cdot 4)^{\star}\end{array}$ & $\begin{array}{l}2 \cdot 7(2 \cdot 0-4 \cdot 3)^{\star} \dagger \\
2 \cdot 7(1 \cdot 8-4 \cdot 3)^{\star}\end{array}$ \\
\hline
\end{tabular}

Values are median (range). $\mathrm{MAC}=$ mid arm circumference. $\mathrm{HC}=$ head circumference.

Statistical differences: ${ }^{\star} 0.05$ compared with normal size, normal growth group. $† 0.05$ compared with small size, normal growth group.

the first ultrasound scan after recruitment and the last scan before delivery. A change in score of greater than -1.5 was used to define fetal growth retardation as this was the cutoff, determined using ROC curves, which best predicted neonatal morphometry indicative of fetal growth retardation ${ }^{17}$ as well as adverse perinatal outcome related to fetal growth retardation. ${ }^{18}$

Immediately after delivery, and before expulsion of the placenta, the umbilical cord was clamped in two places. Three millilitres of umbilical venous blood were collected into a plain tube and centrifuged within five minutes of collection at $3500 \mathrm{rpm}$ for 10 minutes. Aliquots of sera were stored at $-30^{\circ} \mathrm{C}$ until further analysis. Serum IGF-1 was measured, after acid-ethanol extraction of its binding proteins, by radioimmunoassay (RIA) using a polyclonal rabbit antiserum (R557A) raised against purified human IGF-1. ${ }^{19}$ The sensitivity of this assay was $0.07 \mathrm{U} / \mathrm{ml}$. Intra-assay coefficient of variation (CV) values were $11.3 \%$ at $0.23 \mathrm{U} / \mathrm{ml}$ and $6.5 \%$ at $1.23 \mathrm{U} / \mathrm{ml}$. Interassay $\mathrm{CV}$ values were $10.5 \%$ at $0.38 \mathrm{U} / \mathrm{ml}$ and $12.1 \%$ at $0.99 \mathrm{U} / \mathrm{ml}$. Serum concentrations of IGFBP-1 were measured using a specific RIA using purified antigen obtained from Dr S Drop (Rotterdam, Holland). Tracer was prepared by iodination of antigen using the chloamine- $T$ method followed by separation on a short Sephadex G75 column. Antiserum was used at a final dilution of 1 in 10000 which bound about $60 \%$ of iodinated tracer. Bound and free antigen were separated using a solid phase second antibody which was cellulose coated with donkey antirabbit antibody (Sac-Cel, Wellcome, Beckenham, Kent, England). The intra-assay CV was $4 \cdot 4 \%$ at 252 $\mathrm{ng} / \mathrm{ml}$ and the interassay CV was $6.5 \%$ at 290 $\mathrm{ng} / \mathrm{ml}$. GH concentrations were measured using a solid phase immunoradiometric assay with a sensitivity of $0.2 \mathrm{mU} / \mathrm{l}$. Intra-assay $\mathrm{CV}$ values were $5 \cdot 1,2 \cdot 4$, and $2 \cdot 6 \%$ at $0 \cdot 8,4 \cdot 5$, and

Table 2 Umbilical venous blood data according to fetal size and growth

\begin{tabular}{|c|c|c|c|}
\hline & \multirow{2}{*}{$\frac{\text { Normal size }}{\text { Normal growth }}$} & \multicolumn{2}{|c|}{$\begin{array}{l}\text { Small size (abdominal circumference of } \\
<10 \text { th centile) }\end{array}$} \\
\hline & & $\begin{array}{l}\text { Normal growth } \\
(n=35)\end{array}$ & $\begin{array}{l}\text { Growth retardation } \\
(n=18)\end{array}$ \\
\hline $\begin{array}{l}\text { IGF-1 }(\mathrm{U} / \mathrm{ml}) \\
\text { IGFBP-1 (ng/ml) } \\
\text { Growth hormone (mU/l) }\end{array}$ & $\begin{array}{c}0 \cdot 31(0 \cdot 00-0 \cdot 84) \\
186(52-1060) \\
72 \cdot 8(24 \cdot 8-1001 \cdot 0)\end{array}$ & $\begin{array}{c}0.13(0.00-0.94)^{\star} \\
220(36-528) \\
69 \cdot 3(19.4-1235.0)\end{array}$ & $\begin{array}{l}0.05(0.00-0.24)^{\star} \dagger \\
232(76-760) \\
100.4(12.4-1003 \cdot 0)\end{array}$ \\
\hline
\end{tabular}

Values are median (range). IGF =insulin-like growth factor; IGFBP=IGF binding protein. Statistical differences: ${ }^{\star} 0.05$ compared with normal size, normal growth group. +0.05 compared with small size, normal growth group.

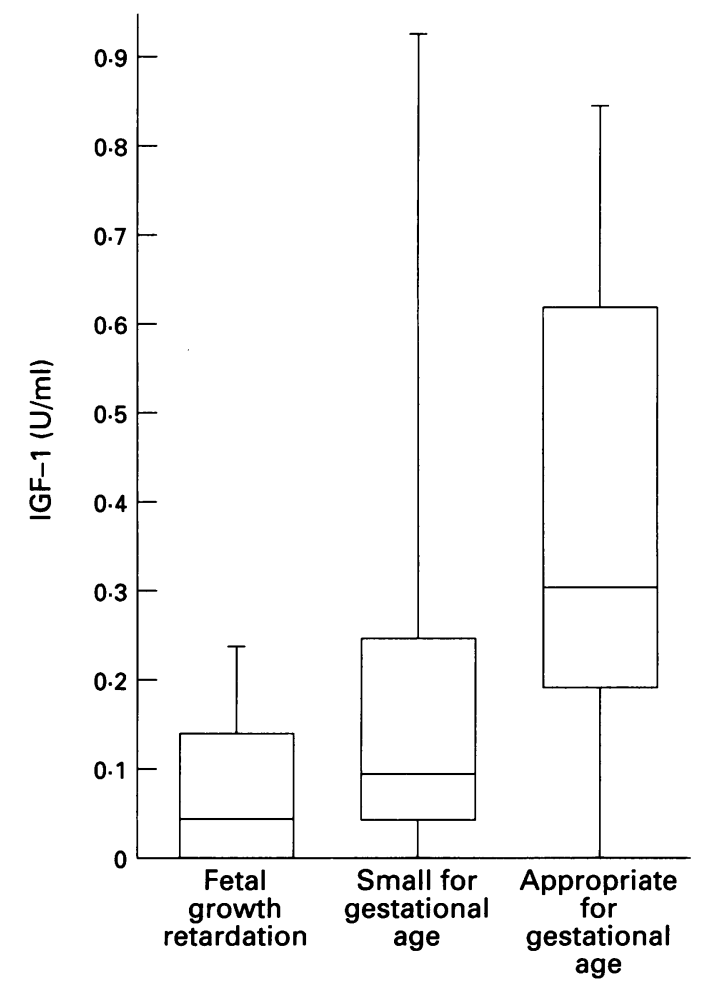

Figure 1 Box and whisker plot (median, range, and interquartile values) of umbilical vein serum concentrations of insulin-like growth hormone-1 (IGF-1) at birth according to fetal size and growth: size small for gestational age with fetal growth retardation; size small for gestational age and normal growth; size appropriate for gestational age and normal growth.

$86.5 \mathrm{mU} / 1$, respectively. Interassay $\mathrm{CV}$ values were $3 \cdot 3,5 \cdot 2$, and $5 \cdot 5 \%$ at $7 \cdot 7,21 \cdot 7$, and $45 \cdot 8$ $\mathrm{mU} / \mathrm{l}$, respectively.

On the second day of life, standard neonatal morphometric indices (ponderal index (PI), mid-arm circumference (MAC):head circumference (HC) ratio, and subscapular and triceps skinfold thicknesses) were determined. ${ }^{20}$ Crown-heel length was measured to the nearest $\mathrm{mm}$ using an 'infantometer' with the head against the head plate and the knees fully extended. The foot plate was brought into contact with the foot in its entire length. Skinfold thickness was measured using Holtain calipers with small surface areas which exert a pressure of $10 \mathrm{~g} / \mathrm{mm}^{2}$ over the whole range of measurements. Mean values for each group of babies were compared.

Fetuses fell into one of three groups according to size and subsequent growth: AGA with normal growth; SGA with normal growth; and SGA with fetal growth retardation. The relation between the different endocrine factors and the change in SD scores were assessed by linear regression analysis. Significance of differences in neonatal morphometric measurements and umbilical vein blood concentrations of growth factors between groups was assessed by the Mann-Whitney $U$ test and accepted if $P<0 \cdot 05$.

\section{Results}

Of the 53 SGA fetuses, 18 showed ultrasound evidence of fetal growth retardation (small size, growth-retarded group) and 35 showed normal growth (small size, normal growth group). All 
Figure 2 Box and whisker plot (median, range, and interquartile values) of umbilical vein serum concentrations of insulinlike growth hormone-1 binding protein (IGFBP-1) at birth, according to fetal size and growth: size small for gestational age with fetal growth retardation, size small for gestational age and normal growth; size appropriate for gestational age and normal growth.

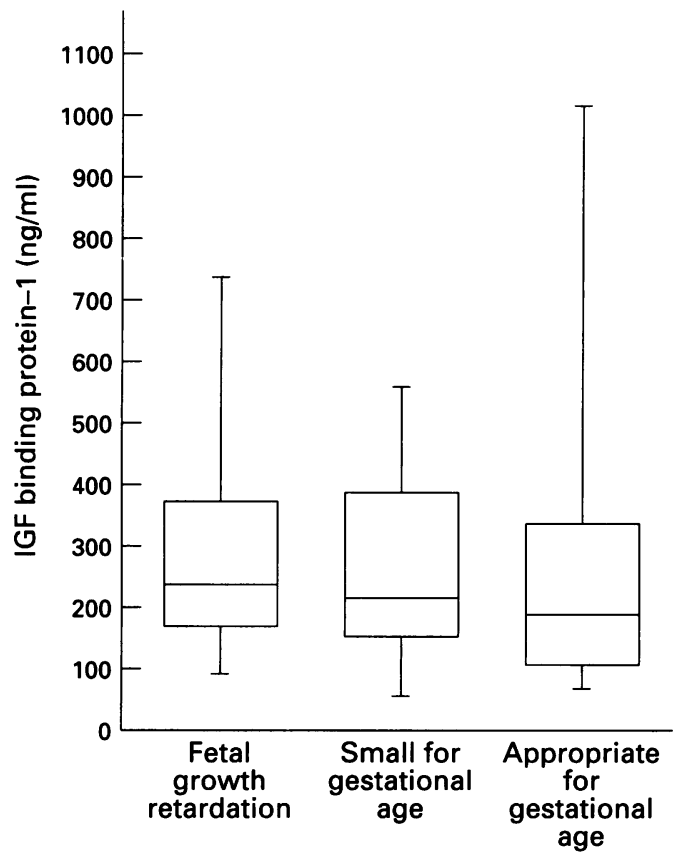

25 of the AGA fetuses had normal antenatal growth (normal size, normal growth group). Median values of birthweight, neonatal PI, MAC:HC ratio, and subscapular and triceps skinfold thickness were significantly different in the three groups, being lowest in the small size, growth-retarded group and highest in the normal size, normal growth group (table 1).

Median umbilical vein concentrations of IGF-1, IGFBP-1, and GH are shown in table 2 and figures $1-3$. Serum IGF-1 was significantly lower in the small size, growth-retarded group compared with both other groups, and was significantly lower in the small size, normal growth group compared with the normal size, normal growth group (fig 1). There were no significant differences between the groups for IGFBP-1 (fig 2) or GH concentrations (fig 3). There was a significant correlation between umbilical vein IGF-1 concentrations and the change in $\mathrm{SD}$ score $(\mathrm{IGF}-1=0.21+0.04$

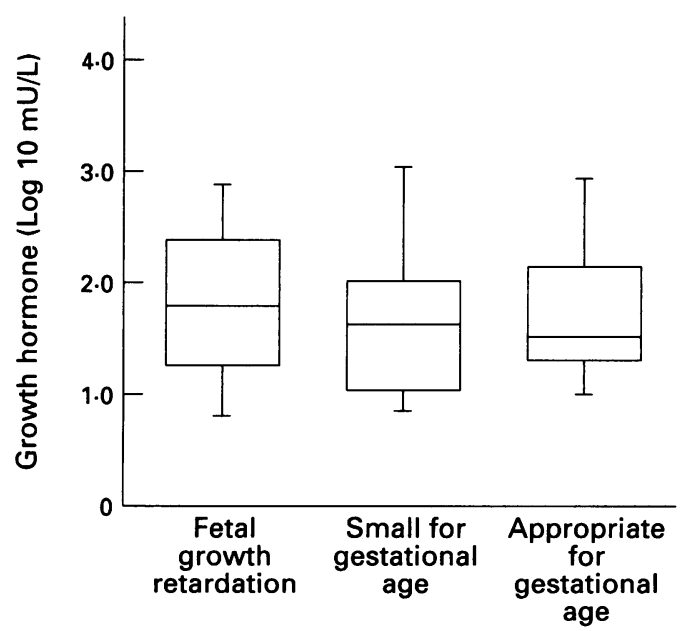

Figure 3 Box and whisker plot (median, range, and interquartile values) of umbilical vein serum concentrations of growth hormone at birth according to fetal size and growth: size small for gestational age with fetal growth retardation; size small for gestational age and normal growth; size appropriate for gestational age and normal growth;
growth. change in $\mathrm{SD}$ score, $\mathrm{SD}=0.015, \mathrm{R}^{2}=8.9 \%$, $P=0.004$ ) as illustrated in fig 4 . There was no significant correlation between change in SD score and IGFBP-1 or GH concentrations.

\section{Discussion}

Previous cross-sectional studies have related circulating concentrations of IGF-1 in umbilical cord blood to birthweight at a variety of gestational ages. Rather than use birthweight as a measure of fetal growth we used serial ultrasound measures of fetal size obtained prospectively during the third trimester of pregnancy. We found a significant correlation between serum IGF-1 concentrations in umbilical venous blood at birth and both fetal size (at recruitment into the study) and growth (change between first and last SD score of abdominal circumference measurement), as assessed by ultrasound during the third trimester of pregnancy. IGFBP-1 and GH concentrations showed no such association with fetal size or growth.

Our method of assessing fetal growth produced three distinct groups in terms of indices of neonatal body proportion as well as birthweight. We have already reported that this methodology identifies abnormal neonatal morphometry indicative of fetal growth retardation in SGA babies. ${ }^{17} \mathrm{~A}$ change in SD scores of -1.5 was determined by ROC curves to be the cutoff point below which fetal growth retardation was best predicted. We have also shown that SGA babies identified as growth retarded by this method are more likely to be delivered by caesarean section, be acidaemic at birth, and be admitted to the neonatal intensive care unit. ${ }^{18}$ The neonatal indices of body proportion clearly show that this methodology is successful in differentiating low birthweight babies into groups with and without evidence of fetal growth retardation.

The relation between fetal growth and circulating concentrations of IGF-1 in umbilical venous blood is in line with the findings of most previous studies which found a positive correlation between birthweight and IGF-1.3-8 One study reported that IGF-1 concentrations were not reduced in SGA babies. ${ }^{21}$ However, in a large study of more than 500 cord samples, IGF- 1 concentrations were $40 \%$ lower in SGA babies and $28 \%$ higher in large-for-dates

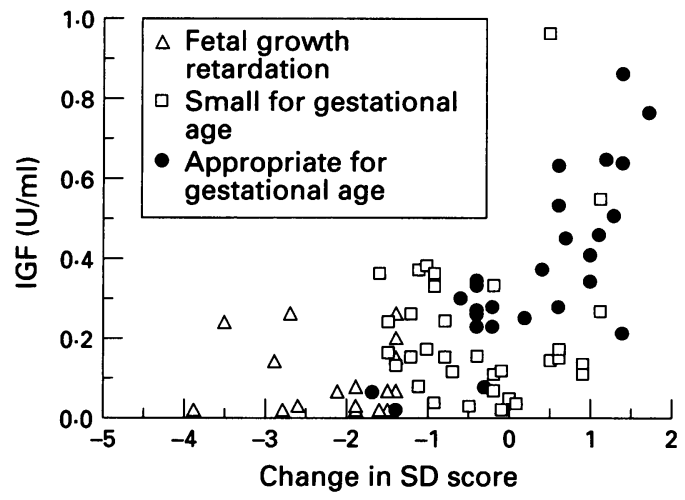

Figure 4 Umbilical vein serum concentrations of IGF-1 plotted according to change in SD score. The three groups of fetal size and growth are shown by different symbols. 
babies compared with AGA babies. ${ }^{6}$ A study of growth restricted fetal sheep also showed a positive relation between IGF-1 and fetal body weight, fetal liver weight, $\mathrm{PO}_{2}$ and glucose at all gestations. ${ }^{22}$ Their model of placental restriction resulted in fetal growth retardation associated with significantly reduced concentrations of IGF-1. This adds weight to our finding of significantly lower concentrations of IGF-1 in SGA babies with fetal growth retardation, and suggests that a real interruption of fetal growth in utero, as opposed to small size (and low birthweight), is related to a reduction in normal placental function.

The bioavailability of IGFs is thought to be determined by the relative proportions of specific IGF binding proteins. Circulating concentrations of IGFs in the fetus are very low compared with adult values but increase throughout gestation. 5811 However, measured concentrations may not reflect bioactivity. IGF-1 and IGFBP-3 concentrations are strongly correlated ${ }^{7}$ and concentrations of both increase substantially with gestation. ${ }^{11}$ The formation of complexes may be one way by which bioavailability of IGF-1 is maintained throughout pregnancy. Three groups of workers have reported an inverse correlation between birthweight and IGFBP-1 61221 and a study of growth restricted fetal rats also showed higher levels. ${ }^{23} \mathrm{~A}$ recent Finnish study also reported an inverse relation between IGFBP-1 in amniotic fluid at 16 weeks' gestation and subsequent birthweight. ${ }^{24}$ However, we did not find a significant relation between IGFBP-1 concentrations and fetal size or growth rate determined by ultrasound despite the range of birthweights in this study. This suggests that the control mechanisms responsible for IGF-1 and IGFBP-1 concentrations are influenced in different ways by the process responsible for fetal growth retardation.

Our methodology did not show any association between concentrations of $\mathrm{GH}$ and fetal size or growth. There is a reported lack of correlation between fetal growth and $\mathrm{GH}, 1325$ and one study reported an absence of $\mathrm{GH}$ receptors in the fetus except in the liver. ${ }^{26}$ However, other studies ${ }^{27} 28$ have confirmed the presence of circulating $\mathrm{GH}$ and widespread tissue receptors (nervous system, mesenchymal, and growth plate). The role of $\mathrm{GH}$ and its association with IGF-1 during fetal life has yet to be fully determined.

The results from our study confirm that IGF1 concentrations are lower in small than normal sized fetuses. The observation that IGF-1 concentrations were lower still in growth retarded small fetuses suggests that IGF-1 may be important in determining fetal growth rate as well as size. Whether these lower concentrations of IGF-1 reflect the mechanism of endocrine control or an overspill from mechanisms at the cellular level remains to be determined.

1 D'Ercole AJ. Somatomedins/insulin-like growth factors and fetal growth. F Dev Physiol 1987; 9: 481-95.

2 Daughaday WH, Heath E. Physiological and possible clinical significance of epidermal and nerve growth clinical significance of epidermal and nerve
factors. $\mathcal{T}$ Clin Endocrinol Metab 1984; 13: 207-11.

3 Bennett A, Wilson D, Liu F, Nagashima R, Rosenfield $R$, Hintz $R$. Levels of insulin-like growth factors I and II in human blood. I Clin Endocrinol Metab 1983; 57: 609-12.

4 Gluckman P, Johnson-Barrett J, Butler JH, Edgar BW, Gunn TR. Studies of insulin-like growth factor-I and -II by specific radioligand assays in umbilical cord blood. Clin Endocrinol 1983; 19: 405-13.

5 Lassarre C, Hardouin S, Daffos F, Forrestier F, Frankenne $F$, Binoux M. Serum insulin-like growth factors and insulin-like growth factor binding proteins in the human fetus. Relationships with growth in normal subjects and in subjects with intrauterine growth retardation. Pediatr Res 1991; 29: 219-25.

6 Verhaeghe J, Van Bree R, Van Herck E, Laureys J, Bouillon R, Van Assche FA. C-peptide, insulin-like growth factors I and II, insulin-like growth factor binding protein-I in umbilical cord serum: correlations with birthweight. $A m \mathcal{F}$ umbilical cord serum: correlation

7 Fant M, Salafia C, Baxter RC, Schwander J, Vogel C, Pezzullo J, et al. Circulating levels of IGFs and IGF binding proteins in human cord serum: relationships to intrauterine growth. Regulatory Peptides 1993; 48: 29-39.

8 Reece EA, Wiznitzer A, Le E, Homko CJ, Behrman H, Spencer EM. The relationship between human fetal growth and fetal blood levels of insulin-like growth factors I and II, their binding proteins, and receptors. Obstet Gynecol 1944; 84: 88-95.

9 Wang HS, Lim J, English J, Irvine L, Chard T. The concentration of insulin-like growth factor-1 and insulin-like growth factor-binding protein-1 in human umbilical cord serum at delivery: relation to fetal weight. $₹$ Endocrinol 1991; 129: 459-64.

10 Shimasaki S, Ling N. Identification and molecular characteristics of insulin-like growth factor binding proteins (IGF-1, $-2,-3,-4,-5,-6)$. Prog Growth Factor Res 1991; 3: 243-66.

11 Band P, Westgren M, Schwander J, Blum WF, Rosenfeld RG, Stangenberg $M$. Ontogeny of insulin-like growth factor-binding protein-1, -2, and -3 : quantitative measurements by radioimmunoassay in human fetal serum. Pediatr Res 1994; 36: 528-36.

12 Crystal RA, Guidice LC. Insulin-like growth factor binding protein profiles in human fetal sera: ontogeny during gestation and differences in newborns with IUGR and LGA newborns. In: Spencer EM, ed. Modern concepts of insulin like growth factors. New York: Elsevier, 1991: 395-408

13 Salardi S, Orsini LF, Cacciari E, Righetti F, Donati S, Mandini $M$, et al. Growth hormone, insulin-like growth factor I, insulin and C-peptide during human fetal life: inutero study. Clin Endocrinol 1991; 34: 187-90.

14 Patterson RM, Pouliot RN. Neonatal morphometrics and perinatal outcome: Who is growth retarded? Am $\mathcal{f}$ Obstet perinatal outcome: Who is

15 Altman DG, Hytten FE. Intrauterine growth retardation: let's be clear about it. Br $\mathcal{F}$ Obstet Gynaecol 1989; 96: 1127-8.

16 Gallivan S, Robson SC, Chang TC, Vaughan J, Spencer JAD. Investigation of fetal growth using serial ultrasound data. Ultrasound Obstet Gynecol 1993; 3: 109-14.

17 Chang TC, Robson SC, Spencer JAD, Gallivan S. Identification of fetal growth retardation: comparison of Doppler waveform indices and serial ultrasound measurements of abdominal circumference and fetal weigh Obstet Gynecol 1993; 82: 230-6.

18 Chang TC, Robson SC, Spencer JAD, Gallivan S. Prediction of perinatal morbidity at term in small fetuses: comparison of fetal growth and Doppler ultrasound. $\mathrm{Br} F$ Comptet Gynaecol 1994; 101: 422-7.

19 Taylor AM, Dunger DB, Grant DB, Preece MA Somatomedin-C/IGF-1 measured by radioimmunoassay and somatomedin activity in adolescents with insulin dependent diabetes compared with puberty matched controls. Diabetes Res 1988; 9: 177-81.

20 Chang TC, Robson SC, Spencer JAD. Neonatal morphometric indices of fetal growth: analysis of observe variability. Early Hum Dev 1991; 35: 37-43.

21 Wang HS, Chard T. The role of insulin-like growth factor-1 and insulin-like growth factor-binding protein-1 in the control of human fetal growth. F Endocrinol 1992; 132: 11-9.

22 Owens JA, Kind KL, Carbone F, Robinson JS, Owens PC Circulating insulin-like growth factors-I and -II and substrates in fetal sheep following restriction of placental growth. $\mathcal{f}$ Endocrinol 1994; 140: 5-13.

23 Unterman TG, Simmons RA, Glick RP, Ogata ES Circulating levels of insulin, insulin-like growth factor-I (IGF-I), IGF-II, and IGF-binding proteins in the small (GF-1), IGF-II, and IGF-binding proteins in the smal

24 Hakala-Ala-Pietila T, Koistinen RA, Salonen RK, Seppal MT. Elevated second-trimester amniotic fluid concentration of insulin-like growth factor binding protein-1 in feta growth retardation. Am $\mathcal{F}$ Obstet Gynecol 1993; 169: 35-9.

25 Grunt JA, Reynolds DW. Insulin blood sugar and growth hormone levels in an anencephalic infant before and afte intravenous administration of glucose. Pediatrics 1970; 76: 112-6.

26 Hill DJ, Freeman M, Strain AJ, Handwerger S, Milner RDG. Placental lactogen and growth hormone receptors in human fetal tissues: relationship to fetal plasma human placental lactogen concentrations and fetal growth. $\mathcal{f}$ Clin Endocrinol Metab 1988; 66: 1283-90.

27 Issakson OGP, Lindahl A, Isgaard J, Nilsson A, Tornell J, Carlsson B. Dual regulation of cartilage growth. In: Carlsson B. Dual regulation of cartilage growth. In: Spencer EM, ed. Modern concepts of insulit
factors. New York: Elsevier, 1991: 121-8.

28 Nilsson A, Lindahl A, Eden S, Isaksson OGP. Demonstration of growth hormone receptors in cultured rat epiphyseal chondrocytes by specific binding of growth hormone and immunocytochemistry. $\mathcal{F}$ Endocrinol 1989; 122: 69-73. 